\title{
CORRIGENDUM
}

\section{Prevalence of dampness and mold in European housing stock}

Ulla Haverinen-Shaughnessy

Journal of Exposure Science and Environmental Epidemiology (2012) 22, 654; doi:10.1038/jes.2012.92

Correction to: Journal of Exposure Science and Environmental Epidemiology (2012) 22, 461-467; doi:10.1038/jes.2012.21; published online 23 May 2012
The Figure 1 legend should have read: "Ranges of mold prevalence values by time frame and survey factor." The Figure 2 legend should have read: "Box plots of water damage and mold prevalence values by region." The author regrets the error. 